\title{
Christian Mission to the Jews Revisited: Exploring the Logic of the Vatican Document "The Gifts and Calling of God are Irrevocable"1
}

\author{
CHRISTIAN M. RUTISHAUSER \\ provinzialat.hel@jesuiten.org \\ Swiss Jesuit Province, 8001 Zurich, Switzerland
}

\section{Introduction}

The 2015 Vatican document The Gifts and Calling of God are Irrevocable ${ }^{2}$ (G\&C) presented systematic theological reflection on the relationship of Judaism and Christianity and thus triggered a new dynamic for today's Jewish-Catholic dialogue. The relationship between the two traditions determining this dynamic emerged within the current Catholic struggle to articulate an adequate theology of religions. ${ }^{3}$ Encouraged by the conciliar declaration Nostra Aetate to recognize the elements of truth within the various religious traditions (NA 2), Catholic theology today struggles to judge them as a whole and to relate to them from an ecclesial point of view. G\&C expresses what can best be described as an inclusivist theology, one which preserves the superiority of its own tradition while admitting the possibility of lesser truths in others. Thus, it defends the universal claim to salvation in Christ Jesus and sets itself apart from pluralists' acceptance of all religious truths as equal. Despite its affirmation of interreligious dialogue, though, G\&C preserves a missionary mandate to lead people to the Christian faith. Mission to the Jews, though, has been one of the sensitive issues in Jewish-Christian dialogue in recent

\footnotetext{
${ }^{1}$ An initial version of this essay was presented at "Fulfilling the Promise of a New Relationship: An Academic Roundtable on Christian-Jewish Relations," sponsored by the Institute for Catholic-Jewish Relations, Saint Joseph's University, Philadelphia (January 2019).

${ }^{2}$ Commission for Religious Relations with the Jews, "The Gifts and the Calling of God are Irrevocable" (Rom 11:29): A Reflection on Theological Questions Pertaining to Catholic-Jewish Relations on the Occasion of the 50th Anniversary of "Nostra Aetate" (No.4),

http://www.vatican.va/roman curia/pontifical councils/chrstuni/relations-jewsdocs/rc_pc_chrstuni_doc_20151210_ebraismo-nostra-aetate_en.html.

${ }^{3}$ Johannes Becker, Catholic Engagement with World Religions: A Comprehensive Study (New York: Maryknoll, 2010); Werner Löser, Bausteine für eine Theologie der Religionen: Blicke und Schritte über die Grenzen (Würzburg: Echter, 2016).
} 
decades, even if rarely addressed explicitly. This article asks if this Christian commitment to mission is applicable to Judaism, and in what sense G\&C deals with this question.

Lying behind the inclusivist theology expressed in $\mathrm{G} \& \mathrm{C}$ are a number of important Vatican documents. Dialogue and Mission (1984) ${ }^{4}$ and Dialogue and Proclamation $(1991)^{5}$ present dialogue about the search for religious truth, on the one hand, and evangelization or mission, on the other hand, as two complementary paradigms for relationship with other religious traditions. They belong together, but each also has its own integrity. The framework of dialogue leads to the discipline of comparative theology which brings individual aspects of different traditions into conversation with each other. Mission, in contrast, though shaped dialogically in that it appreciates the truths of other religions, integrates these truths through the inculturation of the Gospel.

The 2000 Vatican document Dominus Iesus explicitly affirmed this inclusivist theology of religions as official Catholic doctrine. ${ }^{6}$ When it appeared, David Berger and some other Jewish theologians questioned whether and how this theology of religions classified Judaism. ${ }^{7}$ Cardinal Kasper's published response pointed out that "Catholic-Jewish relations are not a subset of interreligious relations in general, neither in theory nor in practice." ${ }^{\prime \prime}$ In other words, among world religions, Christianity has a unique relationship to Judaism. Dominus Iesus, Kasper implied, also defends this unique relationship between Judaism and God against a pluralistic approach. Judaism should, as it were, stand on the side of the Church over and against the religions of the world.

How is this to be understood? Can Catholics ultimately classify Judaism within an inclusivist theology of religions, but in a particularly close relationship to Christianity? Is Christianity surrounded by religious traditions like concentric circles, where Judaism is closest, then Islam follows, and then other religions? While for Jews, the Jewish relationship to Christianity may be theologically analogous to other interreligious relationships, the explanations in G\&C 20 clearly state that, from an ecclesiastical perspective, the Jewish-Christian relationship is indeed sui

\footnotetext{
${ }^{4}$ Pope John Paul II, "The Attitude of the Church Towards the Followers of Other Religions: Reflections and Orientations on Dialogue and Mission (Pentecost 1984), https://www.pcinterreligious.org/pciddocuments.

${ }^{5}$ Pontifical Council for Interreligious Dialogue and the Congregation for Evangelization of Peoples, "Dialogue and Proclamation: Reflection and Orientations On Interreligious Dialogue and the Proclamation of the Gospel of Jesus Christ" (Rome, 19 May 1991), https://www.pcinterreligious.org/pciddocuments.

${ }^{6}$ Congregation for the Doctrine of the Faith, "Declaration Dominus Iesus on the Unicity and Salvific Universality of Jesus Christ and the Church," http://www.vatican.va/roman curia/congregations/cfaith/documents/rc con_cfaith doc 20000806 dominus-iesus_en.html.

${ }^{7}$ David Berger, On Dominus Jesus and the Jews, delivered at the 17th meeting of the International Catholic-Jewish Liaison Committee, New York, May 1, 2001, https://www.bc.edu/content/dam/files/research sites/cil/texts/cirelations/resources/articles/berger.htm.

${ }^{8}$ Walter Cardinal Kasper, "Dominus Iesus," delivered at the 17th meeting of the International CatholicJewish Liaison Committee, New York, May 1, 2001, 2, https://www.bc.edu/content/dam/files/research_sites/cjl/texts/cjrelations/resources/articles/kasper_dominus_iesus.htm.
} 
generis; it is of a different mode than the Church's relationship to other religious traditions. This is not simply a question of relative distance. Because Judaism already answers God's salvific initiative, it stands in an unrevoked covenant with God. Judaism qualifies as a faith tradition, a genuine response to God, as opposed to the world religions that are human-generated beliefs. ${ }^{9}$ Through seven paragraphs (14-20), G\&C unfolds what is stated more implicitly in the conciliar declaration Nostra Aetate. According to NA 1, world religions are to be understood as answers to the great questions of humankind, but NA 4 says that the Church encounters Judaism when she ponders her own mystery. ${ }^{10}$ In defining the nature of the JewishChristian relationship, though, G\&C 37 also emphasizes that Judaism and Christianity are not two parallel ways of salvation. Thus, here too, there is no simple pluralism. The determination of the content of the sui generis relationship between Christianity and Judaism will govern how mission towards Jews is to be understood.

Two Jewish documents reacted to G\&C: a statement of a group of orthodox rabbis, To Do the Will of Our Father in Heaven: Toward a Partnership between Jews and Christians $(2015)^{11}$; and a statement endorsed by the Conference of European Rabbis and the Rabbinical Council of America (both orthodox), Between Jerusalem and Rome: The Shared Universal and the Respected Particular, Reflections on 50 Years of Nostra Aetate (2016). ${ }^{12}$ Beyond all else, both respond positively. They value the fact that Judaism is recognized as an independent religious tradition and that the Church recognizes that Jews stand in a "never-revoked covenant" with God. (G\&C 35-39)

Introduced into discussion by Pope John Paul II, the theological term "neverrevoked covenant" has been widely discussed and has become the concept employed to describe the continuing special relationship between God and Israel with its historical dignity in the postbiblical age. However, reacting to $\mathrm{G} \& \mathrm{C}$ in his essay Grace and Vocation without Remorse published in 2018, Emeritus Pope Benedict

\footnotetext{
${ }^{9}$ Walter Cardinal Kasper, "Dominus Iesus,” 2.

${ }^{10}$ This language points to a continuity with tradition, for across the centuries, the Church knew that she had a special relationship with Judaism. Jews were always distinguished from pagans, heretics and schismatics. See Francis A. Sullivan, Salvation Outside the Church?: Tracing the History of the Catholic Response (Mahwah NJ: Paulist Press, 1992), 14-102. Unfortunately, when it treated the essence of the Church in Lumen Gentium, the Council did not reflect on this constitutive bond to Judaism. But that Lumen Gentium, in its description of the relationship of the Church to the peoples, does not specifically mention Judaism ( $L G \S 1,7$ ), does not mean that Judaism is simply subsumed under them. In the light of the tradition mentioned here, as well as of Nostra Aetate and its ecclesiastical reception, Judaism clearly occupies a special status.

${ }^{11}$ Published December 3, 2015 at http://cjcuc.org/2015/12/03/orthodox-rabbinic-statement-on-christianity/. To Do the Will was published a week earlier than the Vatican text but can to be considered a reaction to it for the Vatican worked on its text for more than two years and some of the authors of To Do the Will were informed about this work in process.

${ }^{12} \mathrm{http}: / / \mathrm{www} . j \mathrm{crelations} . n e t / B e t w e e n$ Jerusalem and Rome - $5580.0 . \mathrm{html}$.
} 
seems dissatisfied with this and considers the language of "never-revoked covenant" to be provisional and imprecise. ${ }^{13}$ For him, God "reestablished" the Sinai covenant in the New Covenant through Jesus Christ. ${ }^{14}$ Thus, apparently, only the Abrahamic covenant (Gen 15:17) maintains its full meaning for Judaism today. But were the Sinai covenant transformed into the covenant of the New Testament, it would be impossible to affirm either the rabbinic tradition and thus today's Judaism, or the principle of God's irrevocable establishment of the covenant.

\section{Christian Mission to the Jews Revisited}

Pope Emeritus Benedict's challenge to this fundamental premise has significant implications for the Catholic theology of religions as applied to Jews. How the different covenants reported in the Bible are related to one another has implications for understanding the special relationship between Christianity and Judaism and thus for our topics: the Church's understanding of both dialogue and of mission.

On dialogue: Church documents explicitly invite Catholics to enter into dialogue with the rich Jewish tradition of interpreting Scripture. The 2001 document of the Pontifical Biblical Commission, The Jewish People and their Sacred Scriptures in the Christian Bible ${ }^{15}$ is a milestone in this respect. The context of Pope Francis' 2013 discussion in Evangelii Gaudium 249 of complementarity between Jews and Christians shows that he had in mind precisely the communities' two traditions of textual interpretation. ${ }^{16} \mathrm{G} \& \mathrm{C}$, though, goes beyond dialogue through biblical hermeneutics. It presents a systematic theological determination of the positive relationship between Judaism and Christianity.

The orthodox Jewish response to this is mixed. To Do the Will also makes theological statements that assess Christianity positively within a Jewish understanding of human history. Between Jerusalem and Rome, however, makes no theological assessment of Christianity. It repeatedly stresses "theological differences," and rejects discussing them. It seems to perceive theological dialogue as the systematic classification and elimination of incompatible and irreducible elements from both faith traditions. Thus, dialogue that extends beyond interpretation of Scripture and mutual social concerns is problematic and threatening to its authors and signatories. Between Jerusalem and Rome focuses instead on a dialogue of common values and actions, coherent with G\&C $48-49 .{ }^{17}$ However, it implicitly

\footnotetext{
${ }^{13}$ Benedikt XVI.-Joseph Ratzinger, "Grace and Vocation Without Remorse: Comments on the Treatise De Iudaeis," Communio 45 (Spring 2018): 168, 180-184, available at https://www.ccjr.us/images/Ratzinger_Grace Vocation_without_Remorse - English.pdf. This is the official English translation of the original German article published in July 2018.

14 "Grace and Vocation," 184.

${ }^{15} \mathrm{http} / / /$ www.vatican.va/roman curia/congregations/cfaith/pcb documents/rc_con_cfaith_doc_20020212_popolo-ebraico_en.html.

${ }^{16} \mathrm{http} / / / \mathrm{w} 2$.vatican.va/content/francesco/en/apost_exhortations/documents/papa-francesco_esortazione-ap 20131124 evangelii-gaudium.html.

${ }^{17}$ As is well known, the contemporary questioning of theological dialogue in Jewish orthodoxy, particularly in the United States, goes back to Rabbi Joseph B. Soloveitchik's reflection "Confrontation," Tradition 6, no. 2 (1964): 5-28.
} 
acknowledges that ethical, social, and political questions can never be completely detached from theological ones. Every dialogue therefore indirectly negotiates theology too.

Christian mission is the central issue here, though. The question of mission to the Jews was first raised in the post-conciliar context at the 1977 meeting of the International Liaison Committee (ILC). The Catholic speaker for the Vatican, Tomaso Federici, ${ }^{18}$ explained that Christian mission follows the biblical and prophetic call to bring God's name to all nations, and is hence a task that Christians and Jews share (I.A.1-9). He then distinguished mission, witness, and proselytism. Any proselytism that exerts moral, ethical, psychological, or physical pressure is incompatible with the nature of the Christian proclamation of faith as understood by the Church. In fact, Federici argued against mission to the Jews (II.A.11-17). Above all, his ethical argument found consensus among the Catholic and Jewish participants. $^{19}$

A broader theological debate on this subject only arose more than twenty years later. It was ignited by the 2002 American document Reflections on Covenant and Mission, issued by a consultation of the National Council of Synagogues and delegates of the Bishops' Committee for Ecumenical and Interreligious Affairs. ${ }^{20}$ Its premise is that Jews are already in covenant with God, and this covenant is neverrevoked. Thus, Jews are already answering God's call and, like Christians, work towards the kingdom of God. The document explicitly states that this covenant includes redemption from bondage, gracious election, sanctification, and all the gifts that Paul enumerates in the letter to the Romans (9:4f.). Its decisive claim is that:

The term mission, in its proper sense, refers to conversion from false gods and idols to the true and one God, who revealed himself in the salvation history with His elected people. Thus mission, in this strict sense, cannot be used regarding Jews, who believe in the true and one God. ${ }^{21}$

Thus, not mission but dialogue determines the Jewish-Christian relationship.

Reflections on Covenant and Mission was fiercely contested by right-wing Catholics, most prominently by Cardinal Avery Dulles, but it served nonetheless as a cornerstone in the post-Nostra Aetate process toward renewed theological thought. Its argumentation recalls the statement of the Jewish philosopher, Franz Rosenzweig. He accepted that Christ was the way to the Father and no one comes to God but through him, but stated that Jews had been with the Father long before

\footnotetext{
${ }^{18}$ https://www.ccjr.us/dialogika-resources/educational-and-liturgical-materials/classicarticles/federici1977.

${ }^{19}$ Hans Hermann Henrix, "Weichenstellungen in katholischen Positionen - von Nostra Aetate bis zu Papst Benedikt," in Das Heil der Anderen: Problemfeld "Judenmission," ed. Hubert Frankemölle and Josef Wohlmuth, QD 238 (Freiburg/ Basel/ Vienna: Herder, 2010), 20-21.

${ }^{20} \mathrm{http}$ ://www.usccb.org/beliefs-and-teachings/ecumenical-andinterreligious/jewish/upload/Reflections-on-Covenant-and-Mission.pdf.

${ }^{21}$ Roman Catholic Reflections, section "Evangelization and the Jewish People."
} 
Christians. ${ }^{22}$ Seven years after the American debate, in 2009, when Pope Benedict was criticized for permitting the Tridentine rite's Good Friday intercession for the Jews because it would reintroduce praying for their conversion, the Central Committee of Catholics and Jews in Germany published the statement Mission to Jews No - Jewish-Christian Dialogue Yes. ${ }^{23}$ It similarly formulates that the Jews will reach salvation without an explicit confession of Christ or baptism because they are in the never-revoked covenant with God (III.3). It also teaches that God's plan of salvation is a mystery and Jews and Christians will be brought together only in eschatological time. Even more, precisely the Jews" "no" to Christ made possible the mission among the Gentiles and thus led to the Church, necessary for the salvation of mankind (cf. Rom 11:11).

In his own writings, Cardinal Walter Kasper, who presided over the Vatican's Commission for Religious Relations with the Jews from 2001 to 2010, reacted both to the controversy over the relationship of the biblical covenants as well as to that over Christian mission to Jews. Adam Gregerman, in his detailed analysis of Kasper's theology, ${ }^{24}$ demonstrates that Kasper presents the Old Covenant of God with the Jews as positive and salvific. This can be understood as consistent with a line of argument that includes Thomas Aquinas, who teaches in his Sentences that, as sign of the Old Covenant, circumcision eliminates original sin. ${ }^{25}$ According to Kasper, the New Covenant does not substitute for the Old Covenant, but the New Covenant is superior because it is more universal; it therefore fulfils the Old Covenant. Consequently, Jews should be led to the New Covenant, even if this means something different from the mission and conversion required for non-Jews. Mission, he says, also includes the right and duty to bear witness to one's own convictions of faith in the universal truth of Jesus Christ. Kasper argues that Christians should be allowed today to bear witness in this way, but only with consciousness of the controversy and irreconcilable points of view between Jews and Christians, and with great sensitivity for the historical injustices done to Jews by Christian mission.

In 2010, Cardinal Karl Lehmann also spoke to the question of mission to the Jews and summarized his reflections in ten points. ${ }^{26}$ These included that a specific

\footnotetext{
${ }^{22}$ Letter to Rudolf Ehrenberg on November 1, 1913, in: Franz Rosenzweig, Der Mensch und sein Werk. Gesammelte Schriften: Briefe und Tagebücher, vol. 1 (Den Haag: Nijhoff, 1979), 134-135.

${ }^{23} \mathrm{https}$ ://ccjr.us/dialogika-resources/themes-in-today-s-dialogue/conversion/zdk09mar9.

${ }^{24}$ Adam Gregerman, "The Desirability of Jewish Conversion to Christianity in Contemporary Catholic Thought," Horizons 45 (2018): 4-24.

${ }^{25}$ Whereas Aquinas attributes salvific meaning to circumcision in his Sentences, he does not do so in his Summa. On the development of his stance, see Richard Schenk, "Covenant Initiation: Thomas Aquinas and Robert Kilwardby on the Sacrament of Circumcision," in Ordo sapientiae et amoris. Image et message de Saint Thomas d'Aquin à travers les récentes études historiques, herméneutiques et doctrinales: Hommage au Professeur Jean-Pierre Torrell OP à l'occasion de son 65e anniversaire, ed. JeanPierre Torrell, Carlos-Josaphat Pinto de Oliveira (Fribourg: University Press, 1993), 555-593. On Aquinas, the Old Covenant and Israel, see Matthew A. Tapie, Aquinas on Israel and the Church: The Question of Supersessionism in the Theology of Thomas Aquinas (Eugene OR: Pickwick, 2014).

${ }^{26}$ Cardinal Karl Lehman, “'Judenmission' - Hermeneutische und theologische Überlegungen zu einer Problemanzeige im jüdisch-christlichen Gespräch," in Das Heil der Anderen: Problemfeld
} 
mission to Jews does not belong in the missionary theology of the Roman Catholic Church, even if the Church historically encouraged or forced Jewish baptism. According to the Church's renewed theology about Judaism after Vatican II, Israel's separation from salvation is only partial and temporary. Its salvation is anchored in the never-revoked covenant, though, for Lehmann, language of equivalent paths to salvation is also problematic. Lehmann believes that in view of the permanent differences between Jews and Christians, new methods must be found to express the Jewish-Christian relationship. Evangelization among Jews is not among them.

These US and European debates, including Cardinal Kasper and Cardinal Lehmann's contributions, made very clear that mission to the Jews cannot be subsumed under the mandate to mission among the nations. This awareness left its traces in G\&C.

\section{God's Guidance of Jews and Christians}

As mentioned above, $\mathrm{G} \& \mathrm{C}$ rejects understanding Judaism and Christianity as parallel means of salvation. At the same time, it avoids teaching that the neverrevoked covenant lacks salvific value. The fact that Judaism participates in salvation is of great consequence in its discussion of mission to the Jews. Paragraph 36 teaches:

From the Christian confession that there can be only one path to salvation, however, it does not in any way follow that the Jews are excluded from God's salvation because they do not believe in Jesus Christ as the Messiah of Israel and the Son of God. Such a claim would find no support in the soteriological understanding of Saint Paul, who in the Letter to the Romans not only gives expression to his conviction that there can be no breach in the history of salvation, but that salvation comes from the Jews (cf. also Jn 4:22). God entrusted Israel with a unique mission, and He does not bring his mysterious plan of salvation for all peoples (cf. 1 Tim 2:4) to fulfilment without drawing into it his "first-born son" (Ex 4:22). From this it is self-evident that Paul in the Letter to the Romans definitively negates the question he himself has posed, whether God has repudiated his own people. Just as decisively he asserts: "For the gifts and the call of God are irrevocable" (Rom 11:29). That the Jews are participants in God's salvation is theologically unquestionable, but how that can be possible without confessing Christ explicitly, is and remains an unfathomable divine mystery.

This paragraph provides the necessary background for paragraph 40's disavowal of targeted mission to the Jews. There we read:

\footnotetext{
“Judenmission," ed. Hubert Frankemölle, Josef Wohlmuth, QD 238 (Freiburg/ Basel/ Vienna: Herder, 2010), 165-167.
} 
The Church is therefore obliged to view evangelization to Jews, who believe in the one God, in a different manner from that to people of other religions and world views. In concrete terms this means that the Catholic Church neither conducts nor supports any specific institutional mission work directed towards Jews.

The document here takes up Cardinal Kasper's language denying any institutionalized mission to the Jews, which he coined and used for the first time in the debate generated by Dominus Iesus, writing:

Thus mission, in this strict sense, cannot be used with regard to Jews, who believe in the true and one God. Therefore-and this is characteristic-[there] does not exist any Catholic missionary organization for Jews. There is dialogue with Jews; no mission in this proper sense of the word towards them. ${ }^{27}$

The terms "missionary organization for Jews" or "institutionalized mission" require elucidation. They translate the German term Judenmission which echoes the history of Jewish mission as it arose in the 19th century among some Protestant Churches. It is a colonialist understanding of mission, motivated by the conviction that Jews have to believe in Jesus Christ before the history of salvation can come to its completion. ${ }^{28}$ Eschatological thinking determines its horizon. In the Catholic Church of that time, only one institutionalized initiative arose to evangelize the Jews with this eschatological motivation, namely the Sisters of Zion, founded by the Jewish convert Théodore Ratisbonne in 1842. In the transition to a new theology of Judaism after the Shoah, though, the sisters abandoned their missionary commitment and placed themselves at the service of dialogue with Jews, becoming its pioneers. The nineteenth-century mission, of course, had earlier roots, but it was not institutionalized in the same way. From the Middle Ages to early modernity, the Catholic mendicant orders systematically sought to convert Jews, this in spite of the doctrine of the double patronage of the Popes who were supposed to protect Jews and Christians from each other. ${ }^{29}$

Indeed, seeking baptism of Jews and their integration into the Church remains Catholic practice today. This is in spite of the 1970 ordinary rite's Good Friday intercession, replacing the Tridentine rite's prayer for Jewish conversion, that petitions God to "grant [Jews] to advance in love of his name and in faithfulness to his covenant." "30 G\&C 40 consequently continues with an affirmation that Christians must be able and allowed to testify to Jews about their faith. It states:

\footnotetext{
${ }^{27}$ Walter Kasper, “Dominus Iesus..., 3.

${ }^{28}$ On the history of the term see Cardinal Karl Lehman, "'Judenmission'..., 146-158.

29 Thomas Brechenmacher, Der Vatikan und die Juden: Geschichte einer unheiligen Beziehung (München: Beck, 2005), 12-26.

${ }^{30}$ Solemn Intercession VI, at http://www.ibreviary.com/m/preghiere.php?tipo=Rito\&id=541.
} 
While there is a principled rejection of an institutional Jewish mission, Christians are nonetheless called to bear witness to their faith in Jesus Christ also to Jews, although they should do so in a humble and sensitive manner, acknowledging that Jews are bearers of God's Word, and particularly in view of the great tragedy of the Shoah.

What does G\&C intend by mission in a "different" and a "humble and sensitive manner"? Does this mean that if there is no institutional mission to Jews, individual Catholics still have a personal one to them? Cardinal Christoph Schönborn seems to suggest this direction when he both speaks out against proselytism, but also, following Paul, wants to proclaim the Gospel to the Jews. He says, “... this mandate must be carried out in the most sensitive way, cleansed of all un-Christian motives. Prayer, the offering of life, tokens of unselfish love and above all recognition of Jewish identity should win 'the goodwill of all the people' (Acts 2:47) for the disciples of Jesus..." 31

In any case, G\&C leaves no doubt about its claim for universal salvation and truth in Jesus Christ. It rejects that the Church in any way replaces Israel, while affirming clearly that the New Covenant in Christ is better than the Old Covenant. The Old Covenant finds its fulfilment in the more universal New Covenant. We need to ask, though, whether we can go beyond expressing merely an ambivalent and dialectical stand about, on the one hand, the mystery that God guides the Jewish people collectively through history, and, on the other hand, God's call to Christians to integrate individual Jews into the Church? Does the call to Christian mission exist only in a tempered manner, with consideration for the fact that Jews are already in covenant with God?

\section{No Evangelization of the Jews}

To answer this, we will need to examine more deeply Section 6 of G\&C titled, "The Church's Mandate to Evangelize in Relation to Judaism" (40-43). It contains elements that will aid us to deepen our reflection. We begin by reviewing the relevant New Testament texts for this "mandate to evangelize" and their historical contexts.

The author of the Epistle to the Ephesians argues for what Luke calls in Acts a "people for his [God's] name" (15:14), ${ }^{32}$ chosen in Christ from the gentiles just as God had chosen the Jews. ${ }^{33}$ Ephesians was written to Christ-believing Jews who have to learn that gentiles are called and chosen by the Messiah too. Eph 1-2's

\footnotetext{
31 Reported in "Karfreitagsfürbitte: Israelitische Kultusgemeinde beendet Dialog," Katholische Nachrichten (Vienna, 17 April, 2008), http://www.kath.net/news/19574. English translation from the Tablet (UK), available at https://www.ccjr.us/dialogika-resources/themes-in-today-s-dialogue/pasttopics/good-friday-prayer/schonborn08mar29.

${ }^{32}$ Bible quotations follow the New Revised Standard Version.

${ }^{33}$ Maria Neubrandt, “'Ein Volk aus Nichtjuden' (Apg 15,14): Die bleibende Erwählung Israels und die Erwählung aus den Völkern im lukanischen Doppelwerk," in Das Heil der Anderen. Problemfeld "Judenmission," ed. Hubert Frankemölle and Josef Wohlmuth, QD 238, (Freiburg, Basel, Vienna: Herder, 2010), 297-310.
} 
central message is that there should be no enmity between the Jewish and gentile communities. ${ }^{34}$ However, even if all are to become one body in Christ and, through him, the hostility between Jews and other peoples will be overcome, it is, from the beginning, not a matter of a single, undifferentiated people of God. To paraphrase Gal 3:28, Jews and Greeks, men and women, remain differentiated, side by side, while also being one in Christ. Paul too, argues with his fellow Jewish Christ-followers for a mission to the gentiles, leading to the emergence of gentile Christian communities. In these Pauline congregations, Christian Jews and Christian gentiles worship together for some time, but a distinction remains. The Torah, with its demarcation between the purity of Israel and the impurity of the nations, has not been abolished, but this demarcation has shifted. Gentile Christians are now in covenant with God too; it is pagan Gentiles who remain outside. What became the Church did not emerge out of Judaism in the sense that Christianity separated from Judaism. It was never an offshoot, or the result of schism. Rather, what we today call the Church originated among the proselytes who gathered around Judaism. ${ }^{35}$ It was a gentile Church from the beginning, alongside Jews and other Messianic movements within Judaism.

Another crucial New Testament text must be mentioned: Rom 11. As is well known, Paul, in his Epistle to the Romans, attempts to express a kind of messianic theology of history. By chapters 9-11, he aligns Jews and people from the nations to one another. He concludes his reflections with a synthesizing metaphor, the famous olive tree parable. Many understood Paul to depict Jews who do not follow Jesus as the broken off branches of the tree and Gentile Christians as the grafted-in wild ones. But contemporary exegesis has revised this view and further differentiated the elements of the parable. Abraham is the root and Christ the trunk of the olive tree. ${ }^{36}$ Moreover, as Mark D. Nanos clarifies, Paul mediates between, not two, but four different groups: Jews who reject Jesus as Messiah, Jews who accept him but are not open themselves to mission among the Gentiles, Jews like Paul who are Christ followers and open to universal messianic mission, and Gentile Christians, that is, people from the nations, who attend the synagogue and accept Jesus as the Messiah. At stake and disputed is the status of this last group. Nanos' close reading of the olive tree parable shows that Paul speaks not about the elimination or falling off of the original branches, but about their breaking, that is, their being cut and bent to the side so as to graft in the wild branches (11:17ff). The Gentile Christians are thus grafted in next to the original olive branches; this is physically painful for them. Paul urges the Gentile Christians, who do not have to convert to Judaism because God is a God of all nations (cf. Isa 25:6; 65:7; Acts 13:47; 15:17), not to

\footnotetext{
${ }^{34}$ Norbert Baumert and Irma Maria Seewan, Israels Berufung für die Völker: Übersetzung und Auslegung der Briefe an Philemon, an die Kolosser und an die Epheser (Würzburg: Echter, 2016), 180281.

${ }^{35}$ Rupert Feneberg, "Die Gründung der heidenchristlichen Gemeinde in Mt 28,16-20," in Das Heil der Anderen. Problemfeld "Judenmission," ed. Hubert Frankemölle/ and Josef Wohlmuth, QD 238, (Freiburg, Basel, Vienna: Herder, 2010), 274-280.

${ }^{36}$ Maria Neubrand, “'Eingepfropft in den edlen Ölbaum' (Röm 11,24): Der Ölbaum ist nicht Israel,” Biblische Notizen, Neue Folge 105 (2000): 61-76.
} 
assert superiority over those Jews who cannot comprehend that the God of Israel is opening to the nations though the Messianic movement (11:18). According to Nanos, even if these Jews do not share Paul's approach, God does not reject them. They are hardened through the cut necessary for the grafting, according to Paul's metaphor. Later however, they will come to understand that the Messianic mission among the Gentiles and the extension of election among them is God-given (11:25ff). This is Paul's hope. Nowhere, however, does he stop Gentile Christians from bringing their faith in Christ to the Jews who are hardened and cannot consent to Paul's project, argues Nanos. ${ }^{37}$

Finally, we must consider Mt 28:16-20, the baptismal command of the resurrected Christ. When Jesus commands his disciples to "make disciples of all nations, baptizing them in the name of the Father and of the Son and of the Holy Spirit" (28:19) to whom are they to go? The traditional and common Church reading of this text never hesitated to claim that the Jews are to be counted among the peoples mentioned here too. But the Matthean Christ speaks from a Jewish perspective and therefore intends the Gentiles when he speaks of "all nations." Contemporary exegetes increasingly accept this interpretation. That Matthew 10 narrates an earlier sending of the disciples through Jesus, explicitly addressed only to the House of Israel, supports this. ${ }^{38}$ The two related missions seem to be complementary. In between, the gospel tells of the death and resurrection of Jesus, exactly the event that establishes the New Covenant. In this, Matthew continues his pattern of repeatedly distinguishing these two groups of addressees. ${ }^{39}$

It is noteworthy that Pope em. Benedict/Joseph Ratzinger refers to Mt 28 when he argues against mission to Jews, calling instead for dialogue. In a short essay in the Herder Correspondence, he interprets this passage in such a way that the Risen Lord's order to missionize and baptize applies only to the nations and not to Israel; he spoke as the Jewish Messiah looking to the world of nations. "For Israel, therefore, there was and is no mission, but a dialogue about whether Jesus of Nazareth is the 'Son of God, the Logos'," Benedict writes. ${ }^{40}$ But of course, this statement only calls for dialogue instead of mission insofar as Jesus Christ is not the only and imposed content of dialogue, and only insofar as Judaism is recognized in its neverrevoked covenant with God beyond the question of Christology. But we saw that Ratzinger asserted in his Communio article that the doctrine of the never-revoked covenant is problematic as the basis for dialogue. Therefore, one may doubt whether Benedict's call for dialogue with the Jews is indeed a dialogue in the common sense, where partners meet on equal terms and freely decide on its form and contents. On the other hand, Benedict indeed opposes traditional mission to the

\footnotetext{
${ }^{37}$ Mark D. Nanos, Reading Romans within Judaism: Collected Essays, (Eugene OR: Wipf and Stock, 2018), Vol. 2, Part III, “'Broken Branches': A Pauline Metaphor Gone Awry? (Rom 11:11-24),"112152.

${ }^{38}$ Feneberg, "Gründung...," 262-274.

${ }^{39}$ Compare the stories of the multiplication of the loaves. There is one in chapter 14 for the Jews where twelve baskets of bread are left over and another for non-Jews from the nations in chapter 15 where seven baskets remain.

${ }^{40}$ Joseph Ratzinger - Benedikt XVI, "Nicht Mission, sondern Dialog," Herder Korrespondenz 12 (2018): 14
} 
Jews. He argues in Jesus of Nazareth that after Christ's resurrection a "time of the Gentiles" dawned in which the nations should be evangelized. He argues, turning to the Gospel of Luke and Acts and quoting Bernard of Clairvaux as source of the tradition that the conversion of the Jews does not have to be taken care of during the time of the nations, because it will be accomplished by God in due time. ${ }^{41} \mathrm{G} \& \mathrm{C}$ 36 quotes Bernard to the same effect.

To summarize the exegetical and theological discussion relevant for understanding Section 6 of G\&C: the arguments presented about the debates on evangelization among Jews and the contemporary exegesis of relevant New Testament passages provide sufficient and systematically grounded justification for delegitimizing a traditional Christian mission to the Jews, whether collective or individual.

A way to express this clearly would be for the Church to celebrate this new and deepened understanding liturgically. It should rename and redesign the Feast of the Conversion of Paul. It is no longer appropriate to celebrate Paul's conversion from Judaism to Christianity, as he remained consciously Jewish during his entire life; rather the Church should celebrate Paul's Christological redirection. ${ }^{42}$ This January $25^{\text {th }}$ feast could be renamed The Calling of Paul, with a corresponding adaptation of the texts of the Mass. In addition, the Church should restore the Feast of Circumcision of our Lord Jesus on the Octave Day of Christmas, on January 1. When the liturgical reform of Vatican II suppressed this feast in 1969, it prevented Catholics from celebrating the God's covenant with the Jews and the fact that Jesus was born and lived under the law (Gal 4:4). This feast could underline the importance of the Old Covenant and its continuing significance for Christians. ${ }^{43}$

\section{Ecclesia ex circumcisione?}

$\mathrm{G} \& \mathrm{C}$ thus perceives that theological reflections, renewed appreciation of Judaism, and exegetical research indicate that a traditional mission to Jews is no longer possible. At the same time, it holds fast to Jesus' universal claim to salvation. Consequently, the text in Section 6 reflects on what evangelization means when applied to Judaism. §41 states that Jesus "calls his Church from both Jews and Gentiles." And $\S 43$ recalls: "It is and remains a qualitative definition of the Church of the New Covenant that it consists of Jews and Gentiles, even if the quantitative proportions of Jewish and Gentile Christians may initially give a different

\footnotetext{
${ }^{41}$ Joseph Ratzinger - Pope Benedict XVI, Jesus of Nazareth, Part II, Holy Week: From the Entrance into Jerusalem to the Resurrection, trans. Philip J. Witmore (San Francisco: Ignatius Press, 2011), 4345.

${ }^{42}$ Daniel Boyarin not only depicts Paul as a messianic Jew with a complex relationship towards Torah but also discusses his way of constructing ethnic and gender identity, which is formative for Jewish and Christian self-understanding still today. Daniel Boyarin, A Radical Jew. Paul and Politics of Identity (Berkeley: University of California Press, 1994), 1-38. 136-157.

${ }^{43}$ Christian Rutishauser, Den christlichen Glauben denken: Im Dialog mit der jüdischen Tradition (Münster: LIT, 2016), 233-248; Jan Heiner Tück, "Beschneidung des Herrn: Warum Papst Franziskus eine Lücke in der katholischen Gedenkkultur schliessen sollte,” Communio 47 (2019): 123-136.
} 
impression." This leads to the question of what kind of importance and meaning Jesus would and could have for Jews and Judaism. If not a traditional Christian mission, then what?

We cannot ignore that the historical Jesus worked entirely within the framework of the Jewish people and turned to his fellow brothers and sisters. The original followers of the Risen One were an inner-Jewish movement; the New Testament understands the crucified and the Risen One as the Messiah, King of the Jews (John 19:1-16). This is something that Christians have tended to forget, but it was raised by Jewish scholars. In the nineteenth century, Abraham Geiger presented pioneering research on Jesus being a Jew of his time. ${ }^{44}$ In the face of Nazi ideology, Leo Baeck not only recalled Jesus as a Jew, but also read the writings of the New Testament as documents of Jewish faith history. ${ }^{45}$ The Gospel of Matthew arose in a Jewish context and is clearly an inner-Jewish scripture. G\&C therefore references the Gospel of Matthew explicitly when it speaks of Jesus' importance for Judaism saying:

He [Jesus] gives his disciples a share in this call in relation to God's people of Israel (cf. Mt 10:6) and then as the risen Lord with regard to all nations (cf. Mt 28:19). Thus the people of God attain a new dimension through Jesus, who calls his Church from both Jews and Gentiles (cf. Eph 2:11-22)... (41)

Following Paul's theology in Rom 11, G\&C 36 also trusts in the mysterious guidance of God, who will save Israel in due course, leading to a convergence of the two communities at the eschaton. Describing the intermediate period of history, Paul speaks both of jealousy between the Church and the Jews (Rom 11:14) and of the role of Jewish disobedience in bringing the gentiles to Christ (Rom 11:31). But, along with his mission to the Gentiles, Paul also struggles to bring Jews to accept Jesus as the Messiah. He woos his Jewish brethren and would even like to be "cut off from Christ" for their sake (Rom 9:3). He calls Christ the one who brings redemption "to the Jew first and also to the Greek" (Rom 1:16; cf. Eph 2:17). Above all, however, he acknowledges a fundamental division of labor: Peter should bring the Gospel to the Jews, while he himself is mainly sent to the Gentiles (Gal 2:7). The Jews are thus clearly among the addressees of the resurrection message after Jesus' death.

Therefore, G\&C names explicitly that the Church's consisting of Jews and Gentiles is part of the essence of the Church, that there is an ecclesia ex circumcisione and an ecclesia ex gentibus. However, G\&C draws no conclusion from this

\footnotetext{
${ }^{44}$ Susannah Heschel, Abraham Geiger and the Jewish Jesus (University of Chicago Press, 1998), 76$105,127-161$.

${ }^{45}$ Leo Baeck, Das Evangelium als Urkunde der jüdischen Glaubensgeschichte (Berlin: Schockenverlag, 1938); translated as "The Gospel as a Document of the History of the Jewish Faith," in Judaism and Christianity, trans. Walter Kaufmann (Philadelphia: The Jewish Publication Society of America, 1958), ch. 2.
} 
dual form of the Church regarding the missionary mandate Jesus gives to his disciples. The Church's dual nature, though, can become a key for our exploration of precisely this question of mission. That the Church exists in two forms means that the universal significance of Jesus Christ differentiates itself. Lk 2:32 says that Jesus is "a light for revelation to the Gentiles and for glory to your people Israel." $\mathrm{He}$ reveals and establishes the New Covenant for the Gentiles, but what could be his significance and the glory for Jews? Or phrased differently: What significance could Jesus Christ have for Jews, the ecclesia ex circumcisione, that means something other than integrating them into the existing Church, the ecclesia ex gentibus? Or just very simply: How would the ecclesia ex circumcision look?

In approaching this sensitive question, let us keep in mind five premises: 1 . Like for Paul, for G\&C, the time of history is first and foremost the time of the Gentiles. Traditional mission to the Jews is not institutionally or individually appropriate for Catholics in this time. 2. The Jews are already in a salvific covenantal relationship with God. 3. If the Christian universal claim focuses on matters of salvation, then it must take into consideration that the salvation of individuals depends not only on their belonging to a community of faith, but also-and more essentiallyon their ethical behavior and actual acts of faith. 4. The Second Vatican Council adopted a declaration dedicated solely to establishing the right to religious freedom, Dignitatis humanae. This must also be valid in the Jewish-Christian relationship. A Jew or a Christian must always be granted the freedom to convert. 5. Systematic theology must also take into consideration that Christian mission in the past inflicted much injustice on Jews.

Beyond these premises, and before Christians answer what Jesus could mean to Jews, they should listen to Jews' own answers. If Christians should contribute, they are well advised to articulate further questions. Might the meaning of Jesus to Jews consist entirely of an invitation to dialogue with Christians? Might it be possible for Jews to recognize the Church not only as a community that participates in the Noahide Covenant, but also as one that is in a covenant that has its foundation in Jesus Christ and in the New Testament? Or following the logic of Paul, might Jews be asked to accept that God has chosen through Jesus a people out of the nations? Or does the meaning of Jesus for Jews consist in retrieving Jesus as a figure of Jewish history, as happened among scholars of the Wissenschaft des Judentums in the nineteenth century, ${ }^{46}$ or as is done by Jews today when reading the NT as a first-century witness to Jewish history? Would Jews' finding meaning in Jesus result in joint study, not just of the Hebrew Bible, but also of the New Testament? Just as Christians are beginning to learn about the Jewish exegetical tradition of the Oral Torah, might not Jews similarly seek to encounter the Christian twofold Bible, the Old and New Testaments, with their theological and spiritual exegetical traditions? Would Jews' finding meaning in Jesus result in a more fully-

\footnotetext{
${ }^{46}$ Walter Homolka presents an overview of the Jewish research on Jesus in modernity in Walter Homolka and Magnus Striet, Christologie auf dem Prüfstand (Freiburg/ Basel/ Vienna: Herder, 2019), 15-70.
} 
fledged, fully mutual dialogue? What happens, though, if some of the Christians or some of the Jews in dialogue are moved and transformed existentially?

Of course, conversion occurs in a variety of forms and cannot be ignored. ${ }^{47}$ Advocacy for religious freedom means that the Church cannot prevent Christians who want to convert to Judaism from doing so. Nevertheless, it should argue in response that according to Pauline theology, such conversions bring no benefit. In addition, from a Christian perspective, Christian converts to Judaism would not have to cancel their relationship to Jesus of Nazareth but would have to transform it.

However, if Jews in an existential and spiritual dialogue feel addressed by the New Testament message or by Jesus Christ, they should not convert to the Church, for it is an ecclesia ex gentibus. Christians should know that the distinction between Jews and Gentiles is a constitutive category of faith. ${ }^{48}$ Jews who discover Jesus for themselves should continue to pursue their own vocation and form a distinct community, an ecclesia ex circumcisione. Neither the Church nor rabbinic Judaism should put obstacles in the way of Jews who feel addressed by the New Testament. Both should trust in the mysterious guidance of God in history. One may conclude that this discrete ecclesia ex circumcisione would keep the Torah, including circumcision as the premier sign of the covenant for males, keeping Shabbat etc., and therefore witnessing the never-revoked covenant. They would express their faith in freedom and fidelity to the Torah, in appreciation of Christianity, but not in conflict with Judaism. The two communities are related to each other, but distinct, as G\&C 43 underlines. Keeping this possibility open challenges all those involved in dialogue to the highest degree. The Christian "no" to mission today would open the way for an ecclesia ex circumcisione, just as the Jewish "no" to Christ Jesus once was factor in the rise of the Church as ecclesia ex gentibus.

Can and should anything be said about the nature of the ecclesia ex circumcisione? Here again, this is not the task of the Church, especially not in light of history and the probability that it would be misunderstood as a new form of Christian mission. The Church must instead continue her independent path of self-conversion. Christians have no active role, then, except to learn to read Holy Scriptures together with Jews with completely new eyes, especially for the New Testament. All Vatican documents invite this. Through this process, one result of which is this article, Christians discover that Jesus has a different mission for his people than for the nations.

\footnotetext{
${ }^{47}$ Schalom Goldman, Jewish-Christian Difference and Modern Jewish Identity: Seven Twentieth-Century Converts (Lanham/ Boulder/ New York/ London: Lexington Books, 2015). Goldman portrays seven persons converting either from Judaism to Christianity or the reverse. Each has a unique selfunderstanding whose logic has no common denominator. Some identify completely with their newly chosen tradition; others claim double identities in very different forms. A more systematic reflection on (Jewish-Christian) conversion is David Pollack, "Was ist Konversion?," in Treten Sie ein! Treten Sie Aus! Warum Menschen ihre Religion Wechseln, Regina Laudage-Kleeberg and Hannes Sulzenbacher, eds. (Berlin: Parthas, 2012), 38-45.

${ }^{48}$ There is a Vicariate of Hebrew speaking Catholic communities in Israel where some members are of Jewish origin. http://www.catholic.co.il/index.php?lang=en
} 
In summary: For the majority of communities, for Jews and Christians alike, the formula "mission no, dialogue yes" is the compass. The Church renounces of any form of missionary activity, as also one of the most recent documents of the Conference of the German Bishops states. ${ }^{49}$ Dialogue in its existential sense is the adequate way of witnessing Christ to Jews from a Catholic perspective. Dialogue is not a sociological strategy but a consequence of faith. Dialogue is a theological paradigm: dia logos, through word and encounter, conversations and friendship. These are the ways of God. At the same time, Jews and Christians must create a space and be open for God's providence, may it be in history or at the eschaton. Both faith communities must listen to the calling of God again and again. A community of the few may come into being, that traditional Christian language calls ecclesia ex circumcisione. It existed in the past and could exist again. Such a community would be an alternative to what we know nowadays as "Jews for Jesus" or "messianic Jews" in so far as it would be guided by the same principle: mission no, dialogue yes. ${ }^{50}$

\footnotetext{
49 “'Gott wirkt weiterhin im Volk des alten Bundes': Eine Antwort der Deutschen Bischofskonferenz auf die Erklärungen aus dem Orthodoxen Judentum zum Verhältnis von Judentum und Katholischer Kirche" (Würzburg, January 29, 2019), https://dbk.de/fileadmin/redaktion/diverse_downloads/presse_2019/2019_-020a-Stellungnahme-zujuedisch-orthodoxen-Erklaerungen.pdf.

${ }^{50}$ The convert Daniel Rufeisen sought to create a Jewish-Catholic community. See my forthcoming "Oswald Shmuel Aaron Daniel Rufeisen: Jüdisch-christliche Differenz und Identität," Jerusalemer Theologisches Forum 43 (2019).
} 